研 究

\title{
耳管の硬組織非脱灰研磨標本
}

\author{
広野 喜信 -内藤泰・本庄縓 \\ 森 千里*・星野 一正*
}

\section{Undecalcified Ground Sections of the Eustachian Tube}

\author{
Yoshinobu Hirono, Yasushi Naito, Iwao Honjo, \\ Chisato Mori and Kazumasa Hoshino
}

(Kyoto University)

Undecalcified ground sections can be made by polyester resin embedding. With this technique serial vertical and horizontal sections of the eustachian tube of the human cadaver can be prepared in 1 month. The time required is much shorter than the conventional celloidin section method which usually takes at least 6 months. The results were comparable to those of the celloidin sections for anatomical study of the eustachian tube.

Key words: polyester resin embedding, undecalcified ground section, eustachian tube

はじめに

樹脂包埋は電子顕微鏡による観察を目的に始 められたもので，メタクリレート，スチレン， エポキシ，ポリエステルなどの樹脂を用いる方 法が開発されててきた。 パラフィン包埋に比べ細 胞内構造保存に優れ, 酵素活性や抗原性も失わ れないので, 最近, 光学顕微鏡標本作成にも応 用されている(1)2). また樹脂包埋すると, 骨組 織を脱灰せずに薄切, 研磨でき, 類骨と石灰化 骨を判別できるので, 骨の組織学的動態計測に 応用されている

われわれは樹脂包埋による硬組織非脱灰研磨 標本を側頭骨に応用して, 耳管の垂直断および
水平断の連続切片を短期間で作成し，耳管およ び周囲組織の形態を観察できたので報告する。

\section{対 象}

ホルマリン固定の 82 才女性の屍体頭部で，右 側は耳管長軸に垂直な, 左側は水平な連続切片 を作成した。

$$
\text { 方 法 }
$$

1.トリミング

最初に頭部を矢状面で正中断した。耳管は概 ね外耳道上端と硬口蓋前下端を含む水平面内を 走行するので, この平面に平行な上 $2 \mathrm{~cm}$, 下 3 $\mathrm{cm}$ 距離の面で, 大型ボーンカッター（マルト - MC-901) を用いて切断した。後方は外耳道 
後端で正中面に垂直に，前方は耳管咽頭口を明 視下に技き，後面から $5 \sim 6 \mathrm{~cm}$ の距離で正中面 に垂直に，外側は鼓膜を標本に含め正中面から 約 $5 \mathrm{~cm}$ の距離で正中面に平行に切断した（図 1 ).

2. 樹脂包埋（表 1 ）

(1) 脱水, アセトン置換

エタノールで十分に脱水した（12日間）後, アセトンに 2 日間ずつ 2 回通してエタノールを アセトンに置換した.

(2) 樹脂浸透

樹脂はポリエステル系のマルトー硬組織包埋 樹脂 $\mathrm{A}$ 液と B液の $8: 2$ の割合の混合液に, 容 量比で $1.5 \%$ の重合促進剂を加えたものを用い た. 樹脂 $30 \%$ とアセトン $70 \%$ の混合液に組織 片を入れ, 樹脂真空含浸装犆（マルトーMD200）で 2 日間真空吸引した。 次に樹脂 $50 \%$ 之 アセトン $50 \%$ の混合液の中で, 組織片から気泡 が生じなくなるまで約 4 日間真空吸引した。最 後に樹脂 $100 \%$ に移し, 約 2 日気泡が出なくな るまで真空吸引し, 樹脂浸透を完了した.
(3) 重合硬化

$50^{\circ} \mathrm{C}$ で 8 時間, $60^{\circ} \mathrm{C}$ で 8 侍間加温し, 室温で 約 4 日間放置し重合硬化させた。 な打硬化の 際, 組織片の切断面を容器の底に接するように した.

3. 薄切

(1) 包埋した組織片のトリミング 余分の樹脂をマルトーカッター（MD-101） で切断し，さらに耳管の垂直断に用いた組織片 では, 耳管長軸に垂直に切断するため, 図2の

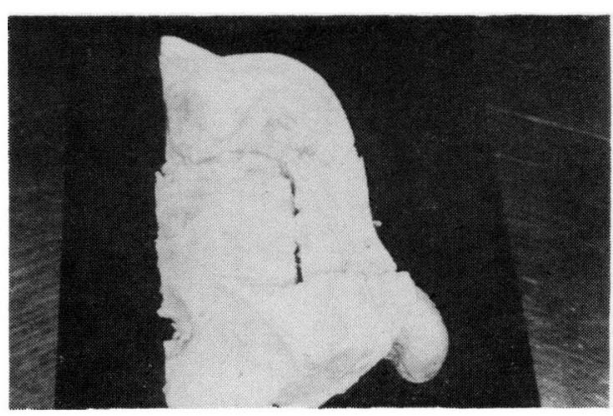

図।頭部のトリミング

表 I 樹脂包埋の方法

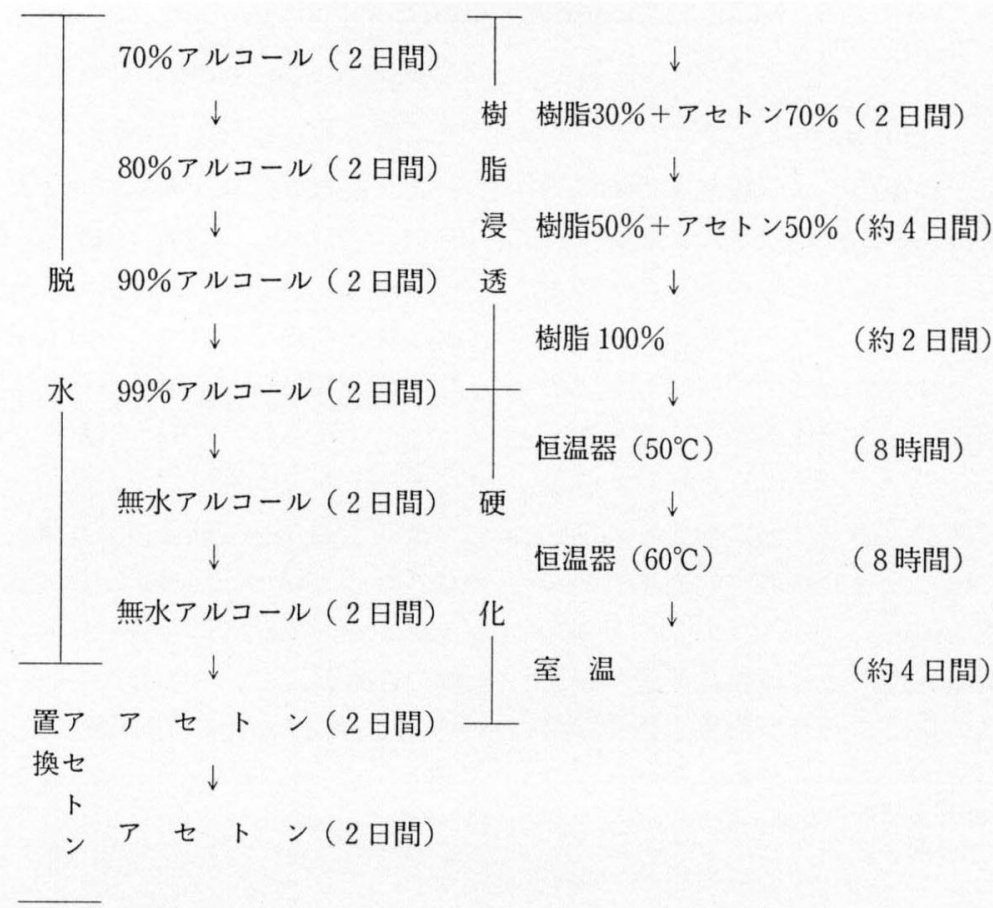


ごとくトリミングした。

(2) マウント

垂直断では下面，水平断では外側面を素焼の マウント台に瞬間接着剂で接着した。

(3)薄切

マウントした組織片をクリスタルカッター （マルトーMC-411）に装着し, 直径 $150 \mathrm{~mm}$, 厚 さ $0.6 \mathrm{~mm}$ の MD式ダイヤモンドブレードで切断 した。 これで高さ $40 \mathrm{~mm}$, 長さ $80 \mathrm{~mm}$ まで薄切可能 である. $1.2 \mathrm{~mm}$ 毎に連続切片を作成し，厚さ400

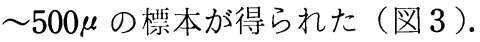

4. 研摩

H T 式㹬組織吥摩装置を用いた。切片をのり

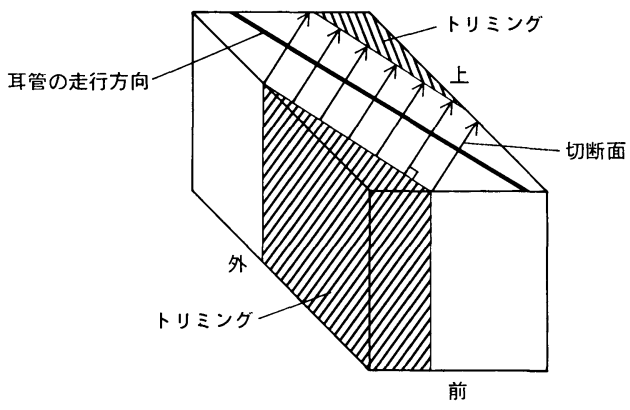

図 2 垂直断に用いた組織片のトリミング

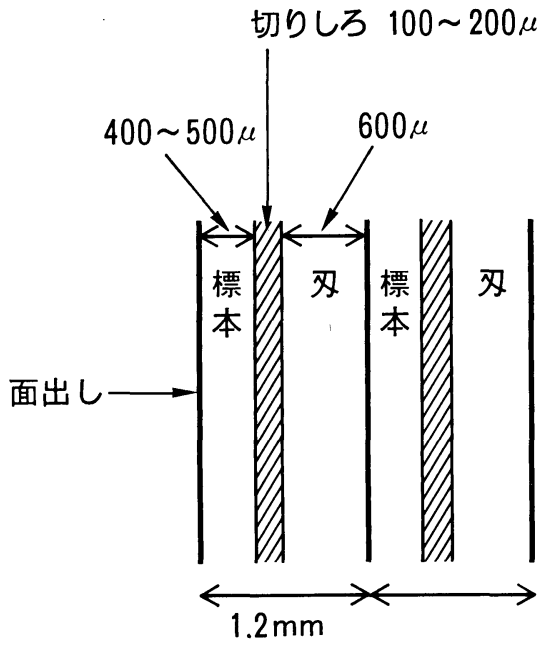

図 3 クリスタルカッターによる薄切
付耐水研摩紙（800番）に水貼し，鏡面に水貼 した耐水研摩紙（1500番）で, 厚さ約 $200 \mu$ ま で研摩した。

\section{5 . 染色}

耳管軟骨，筋肉，骨，腺組織等を色彩で明瞭 に識別するために，トルイジン青，へマトキシ リン，エオジンの重染色を行った（表 2 ）。通 常のへマトキシリン，エオジン染色も行った.

\section{結 果}

1. 耳管の垂直断（図4 )

軟骨はやや赤みがかった青に，腺組織は青 に，筋肉は赤に，骨は赤褐色に染まった。(1)耳 管軟骨の形態，(2)口蓋帆張筋，口蓋帆挙筋の走 行, (3)耳管粘膜下組織, ローゼンミューラー窩 の状態，(4)頭蓋底，内頸動脈之耳管之の関係が 明確に示された。口蓋帆張筋は耳管咽頭口付近 では頭蓋底に付着し（図 $4 \mathrm{~A}$ )，耳管軟骨部中 央部でのみ耳管軟骨に付着していた（図 $4 \mathrm{~B}$ ).

\section{2. 耳管の水平断（図 5 ）}

(1)耳管の走行は直線ではなく，前方に曲がっ ていること（図 5 A)，(2) 口蓋帆張筋が耳管外 側の軟部組織に付着していると思われること (図 5 B), (3)口蓋帆挙筋の走行と軟口蓋への放 射状の停止（図 $5 \mathrm{C}, \mathrm{D}$ ), (4)ローゼンミュー

表 2 染色方法

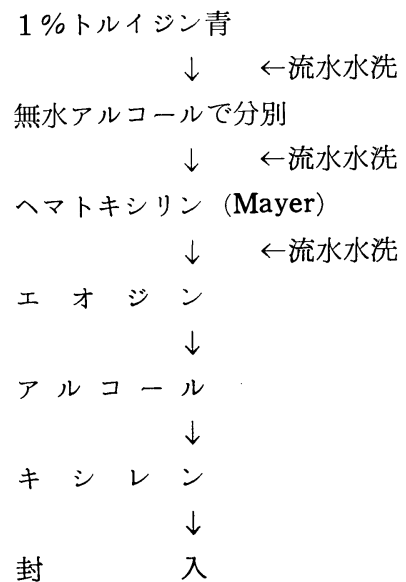




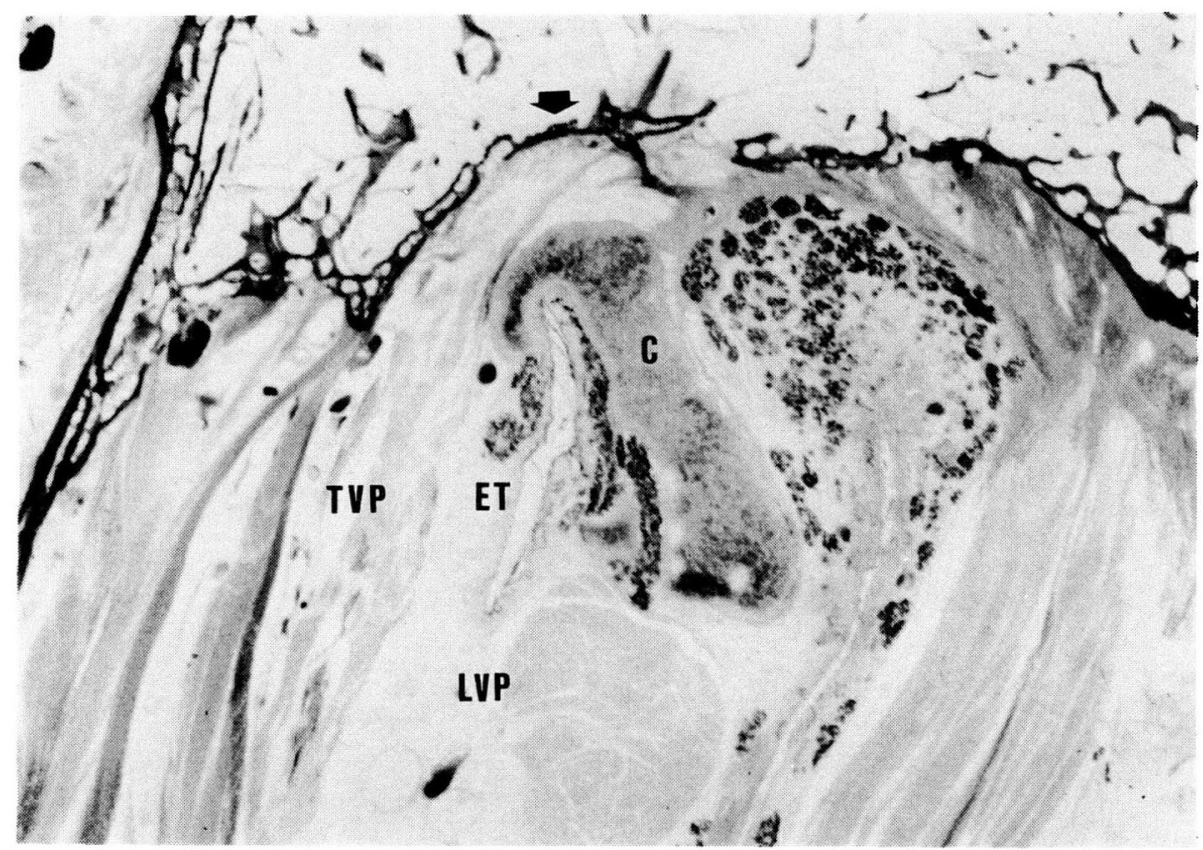

図 4 A 耳管咽頭口付近の垂直断

E T一耳管 C一耳管軟骨 T V P 一口蓋帆張筋 L V P 一 口蓋帆挙筋 $\Rightarrow$ 一帆張筋の頭蓋底への付着

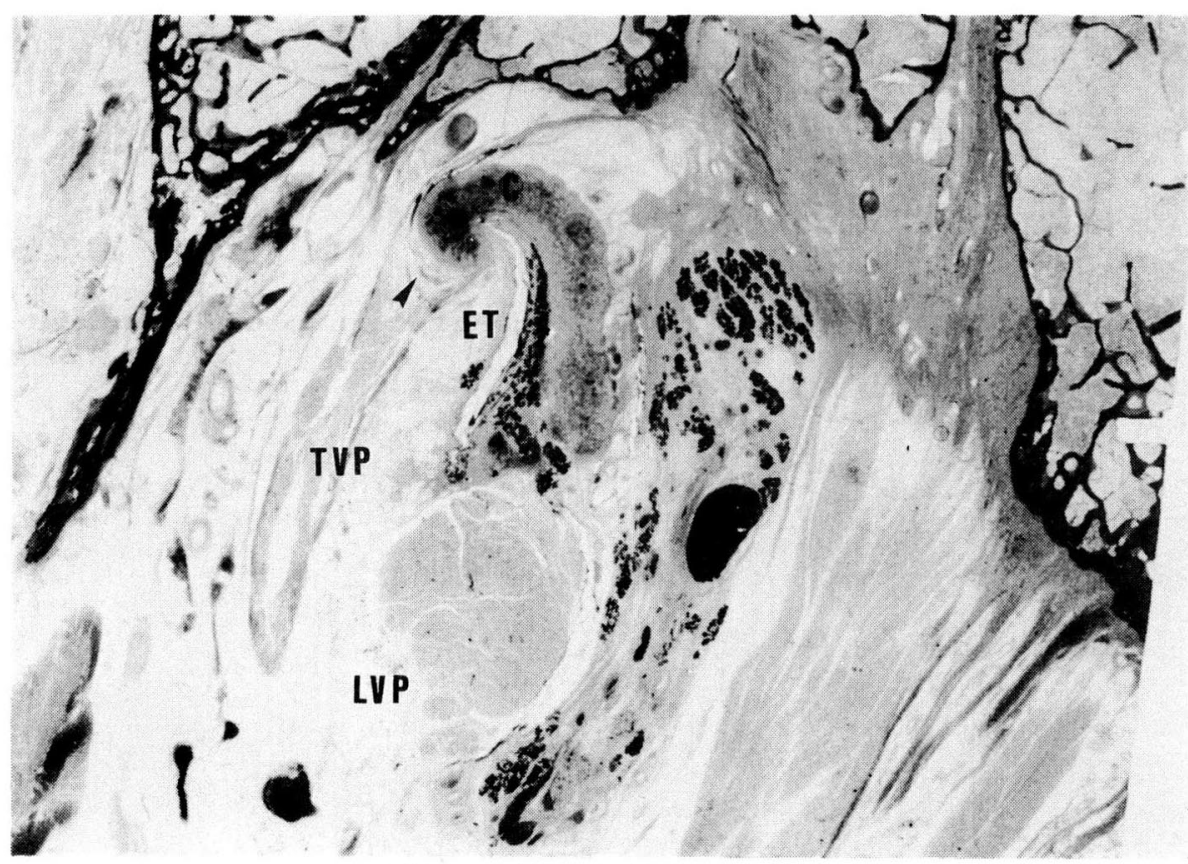

図 4 B 耳管軟骨部中央部の垂直断

E T一耳管 C一耳管軟骨 T V P 一口蓋帆張筋 L V P 一 口蓋帆挙筋 一一帆張筋の耳管軟骨への付着 


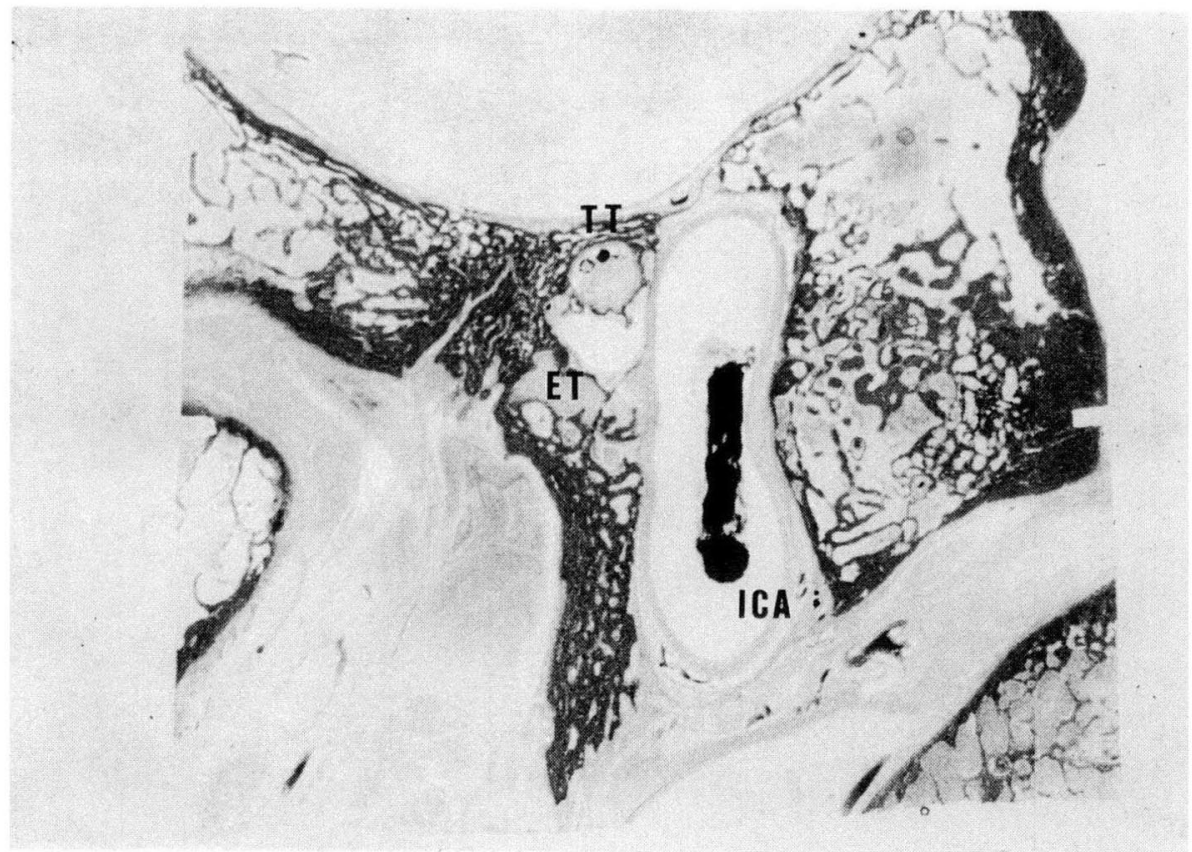

図 4 C 耳管骨部の垂直断（ヘマトキシリン・エオシン染色） E T一耳管 T T 一鼓膜張筋 I C A 一内頻動脈

ラー窩の広がりが明確に示された。

\section{考案}

耳管およびその周囲組織の解剖学的研究は古 くから行われている。しかし従来の報告はいず れあ脱灰操作を必要とするセロイジン包埋法に よるものであっだ) 9). そのため薄切までに少 なくとも 6 力月を要する ${ }^{9 !}$. 樹脂包埋による硬 組織非脱灰標本では，1 力月で標本が完成し， 従来の方法と比して著しく早く結果を得ること ができた。染色性も良好で，耳管やその周囲組 織の形態観察を目的とするなら，七ロイジン包 埋の切片之遜色なかった（図 4,5 ）。連続切 片は $1.2 \mathrm{~mm}$ 毎に作成したが，耳管やその周囲組 織の構造を把握するのに十分で, 三次元グラフ ィクスによる耳管の立体構築の基礎データとな った ${ }^{10)}$. また核磁気共鳴画像との対比にも利用 できた ${ }^{11)}$.

今回は肉眼解剖的な観察を目的としたので厚 さ約 $200 \mu$ の非脱灰研摩標本を作成し, 細胞レ
ベルの組織学的観察は不能であった. しかし H T式硬組織研摩装置を用いた手による研摩です 熟練すれば $50 \mu$ まで薄くできる．また機械式 研磨機（マルトースピードラップML-150Dc） を用いれば $10 \mu$ まで研磨でき，セロイジン包 埋法のマイクロトームで薄切した標本と同等に 組織学的観察が可能である.

成人耳管の長軸に水平な切片による解剖学的 な研究は少ない(4)。耳管之上咽頭との関係，口 蓋帆張筋，口盖帆挙筋の軟口蓋への走行方向 等, 垂直断ではわかりにくい情報が得られ, 耳 管やその周囲組織の解剖学的理解に必要である と思われた。

\section{まとめ}

樹脂包埋による硬組織非脱灰研摩標本で, 耳 管の垂直断および水平断の連続切片を 1 力月で 作成し, 耳管およびその周囲組織の形態を観察 できた。 


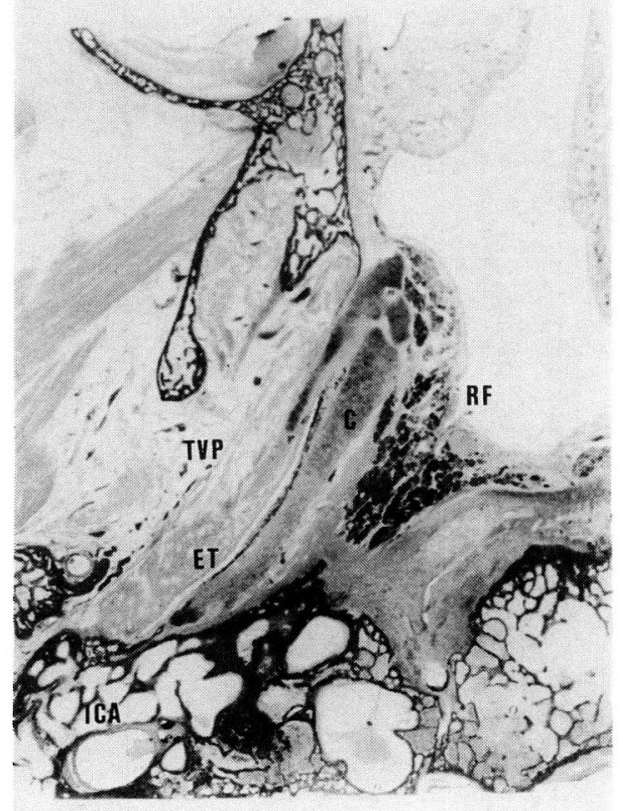

A：耳管上部

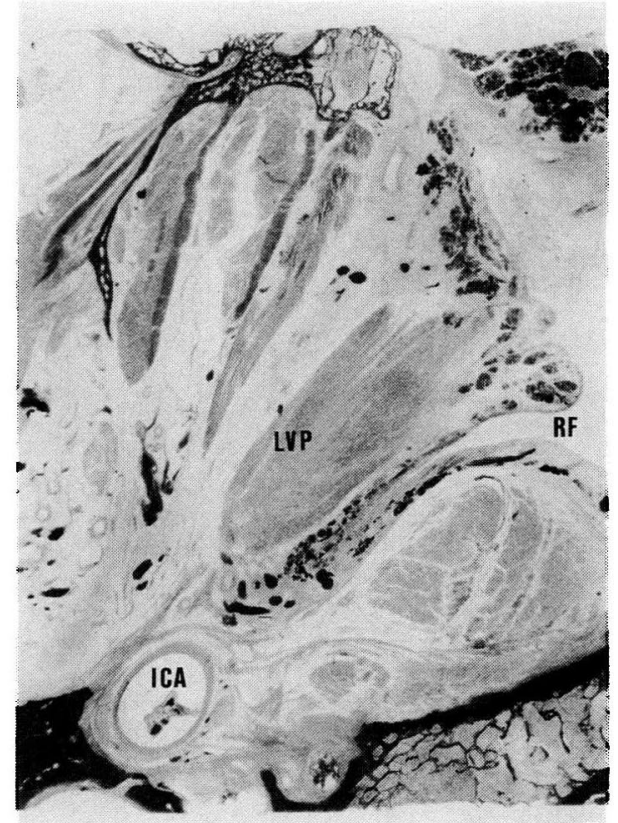

C：耳管より下部

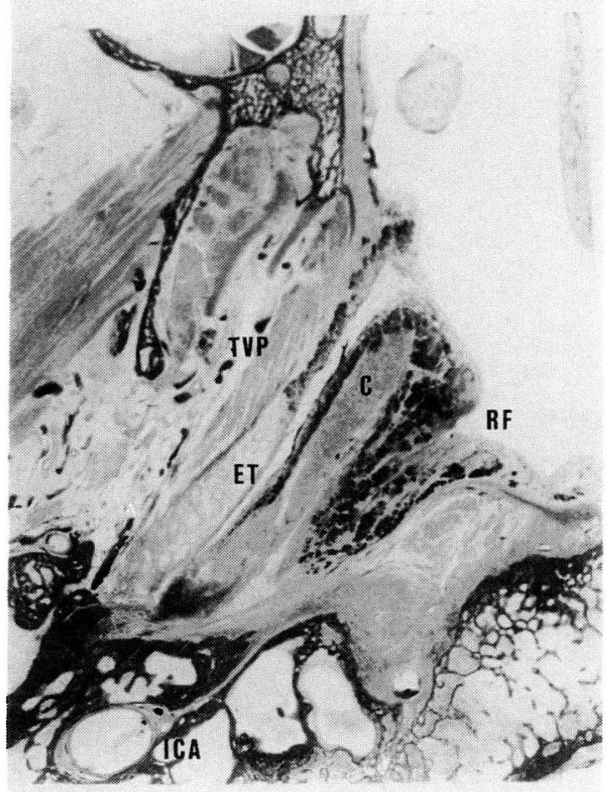

B：耳管中央部

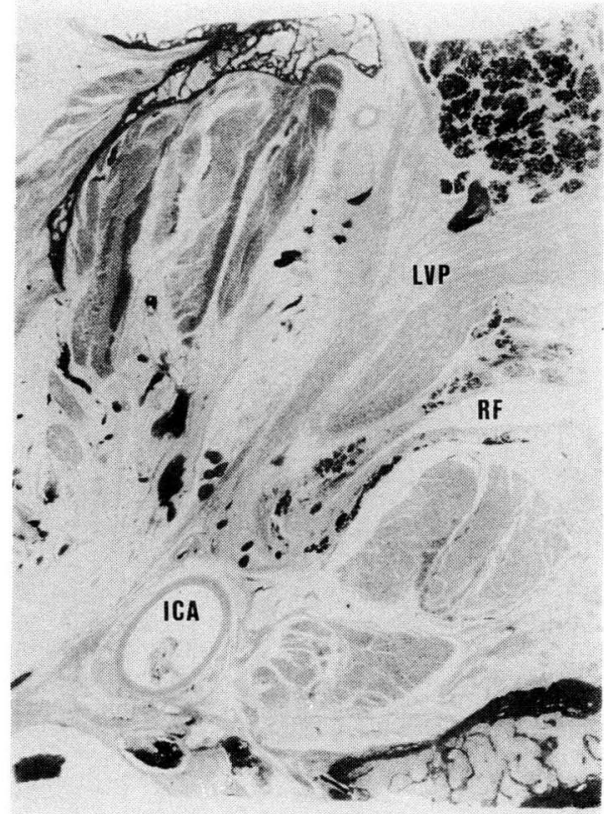

$\mathrm{D} ： \mathrm{C}$ より約 $3.6 \mathrm{~mm}$ 下方

図 5 耳管の水平断

E T一耳管 C一耳管軟骨 T V P 一口蓋帆張筋 L V P 一口蓋帆挙筋

I C A 一内頸動脈 R F 一ローゼンミューラー窝 


\section{参考文献}

1 ) 瀬野尾章, 他: 光顕用樹脂包埋法とその特徴 Medical Technology II: 335 340, 1983.

2) 勝又 修, 他：光学顕微鏡標本作製への迅速凍結 置換樹脂包埋法の導入. 病理と臨床 $2: 726$ $730,1984$.

3) 今野俊幸, 他：非脱疢骨薄切切片のためつ包埋染 色法. 骨形態計測 (高橋栄明編). $1 \sim 8$ 頁, 㗨歯 薬出版, 1981 .

4) Zöllner F : Anatomie, Physiologie, Pathologie und Klinik der Ohrtrompete und ihrer diagnostisch therapeutischen Beziechungen zu allen Nachbarschaftser-krankungen.

Hals-, Nasen-, Ohrenheilkunde der Gegenwart Berlin Springer-Verlag, 1942.

5 ) Graves GO, et al : The eustachian tube. Arch Otolaryngol $39: 359 \sim 397,1944$.

6) Aschan G: The anatomy of the eustachian tube with regard to its funtion. Acta Soc Med Upsal 60:131 149, 1955.
7 ）上村卓也：耳管とその周囲組織つ機能的構造. 耳 鼾と臨床 $7: 184 \sim 200,1961$.

8 ) Djeric D, et al : Anatomical variations and relations of the bony portion of the eustachian tube. Acta Otolaryngol (Stockh) 99 : 543 550, 1985.

9) Sando I, et al : A method for the histopathological analysis of the temporal bone and the eustachian tube and its accesory structures. Ann Otolaryngol $95: 267 \sim 274,1986$.

10）森一功，公野喜信，本庄 厳：耳管刀三次元コ ンピューターグラフィックス. 日耳鼻 $90: 736 〜$ $740,1987$.

11) Naito $Y$, Hirono $Y$, Honjo I, et al : magnetic resonance imaging of the eustachian tube : A correlative anatomical study. (submiffed)

原稿採択：昭和62年 2 月16日 別刷請求先：広野喜信 于650 神户市中央区港島 4-6 神开市立中央市民病院耳鼻咽喉科 